\title{
ARTHROSCOPIC MANAGEMENT OF MENISCAL INJURIES IN ADOLESCENTS: OUTSIDE-IN SUTURING VERSUS MENISCAL DART TECHNIQUE
}

\author{
Zenon Pogorelić ${ }^{1,2}$, Ema Puizina ${ }^{2}$, Miro Jukić ${ }^{1}, J_{a k o v}$ Meštrović ${ }^{1}$, \\ Irena Pintarić ${ }^{3}$ and Dubravko Furlan ${ }^{1}$ \\ ${ }^{1}$ Department of Pediatric Surgery, Split University Hospital Centre, Split, Croatia; \\ ${ }^{2}$ University of Split, School of Medicine, Split, Croatia; \\ ${ }^{3}$ Department of Anatomy, University of Split, School of Medicine, Split, Croatia
}

\begin{abstract}
SUMMARY - The aim of this study was to evaluate clinical and subjective outcomes of the meniscal dart technique in patients having undergone arthroscopic meniscal repair by comparing it with the outside-in suturing technique. From January 2006 until June 2017, case records of 37 patients having undergone arthroscopic meniscal repair were retrospectively reviewed. The patients were divided into two groups based on the technique used for meniscal repair, as follows: 18 patients in suture technique group and 19 patients in meniscal dart group. Each patient was analyzed for the following parameters: age, gender, mechanism of injury, side of injury and injured meniscus, injury localization regarding anatomic position, injury type and associated injuries. The patients that underwent meniscal repair were analyzed for type of repair technique, operating results and results of follow-up (Lysholm and International Knee Documentation Committee (IKDC) score). There were no statistically significant differences between the groups according to clinical outcomes except for anatomic injury localization $(\mathrm{p}=0.035)$. Median of operation time was $62.5 \mathrm{~min}$ in suture technique group and $70 \mathrm{~min}$ in meniscal dart group ( $\mathrm{p}=0.184)$; median of hospital stay was 2 days for both groups ( $\mathrm{p}=0.951)$; median of Lysholm score was 86.5 and 84.5 ( $\mathrm{p}=0.651)$; and median of IKDC score was 81.05 and 81.6 , respectively $(\mathrm{p}=0.986)$. Understanding the harmful impact of meniscectomy, arthroscopic meniscal repair should be attempted whenever possible. Our data support arthroscopic repair of meniscal tears, since both the suture technique and the meniscal dart technique are safe and successful in meniscal repair in children, with good long-term results and without important complications.
\end{abstract}

Key words: Meniscus; Meniscal repair; Children; Meniscal dart; Suture; Artbroscopy

\section{Introduction}

Meniscal injuries are one of the most commonly treated conditions in knee surgery today ${ }^{1}$. In the population of young patients, different sports are the most

Correspondence to: Assoc. Prof. Zenon Pogorelic, $M D, P h D$, Department of Pediatric Surgery, Split University Hospital Centre, Spinčićeva 1, HR-21000 Split, Croatia

E-mail: zpogorelic@gmail.com

Received October 3, 2018, accepted January 28, 2019 common causes of meniscal injury (football, basketball, soccer, baseball and skiing). The mechanism of injury includes rotation, hyperextension, or actions of great force upon the knee. Diagnosis greatly depends on detailed patient history, physical examination and imaging techniques. The most frequent presentation of meniscal tear is a history of sudden sharp pain after rotation of flexed knee and fixed feet on the ground. Meniscal tear is in more that $80 \%$ of cases associated with anterior cruciate ligament rupture ${ }^{2}$. Patients also 
complain of swelling, 'locking', and other mechanical symptoms, while during physical examination joint line tenderness and effusion can be found ${ }^{3}$. Subtotal knee meniscectomy was one of the most common operation procedures used in treating meniscal rupture ${ }^{4}$. The loss of meniscal tissue increases contact pressure across articular cartilage, which results in earlier development of degenerative joint disease. This has led to development of surgical techniques used in meniscal tear repair ${ }^{1}$. Using meniscal repair techniques instead of subtotal meniscectomy, the harmful long-term outcomes can be avoided ${ }^{4}$. The new meniscal repair techniques include all-inside (meniscal arrows, darts, staples, and other suture devices), inside-out and outsidein techniques, and according to the literature, the latter is technically simple with promising clinical results while also avoiding osteoarthrosis and other major complications after meniscectomy ${ }^{5}$.

The aim of this study was to analyze clinical and subjective outcomes in patients having undergone arthroscopic meniscal repair using outside-in suturing technique and meniscal dart technique.

\section{Patients and Methods}

\section{Patients}

Case records of 42 children (26 male and 16 female) having undergone arthroscopic meniscal repair from January 2006 to June 2017 were retrospectively reviewed. The study was carried out as a retrospective cohort trial. Informed consent was obtained from parents or legal guardians of all patients and the institutional Ethics Committee approved the study.

The study included patients of both genders aged 0 to 18 and treated with arthroscopic meniscal repair techniques (meniscal suturing or fixation with meniscal dart). The exclusion criteria were as follows: patients older than 18 years of age, patients operated on with other techniques (meniscus shaving or resection), patients with follow-up shorter than 12 months and patients with incomplete data. Five patients were excluded from the study because they met one or more of the exclusion criteria or were lost from follow-up. A total of 42 patients were included in the study; five patients were excluded because they had follow-up shorter than 3 months or incomplete data. Following that, 37 patients (23 male and 14 female) participated in the follow-up examination (Fig. 1). In all patients, data on

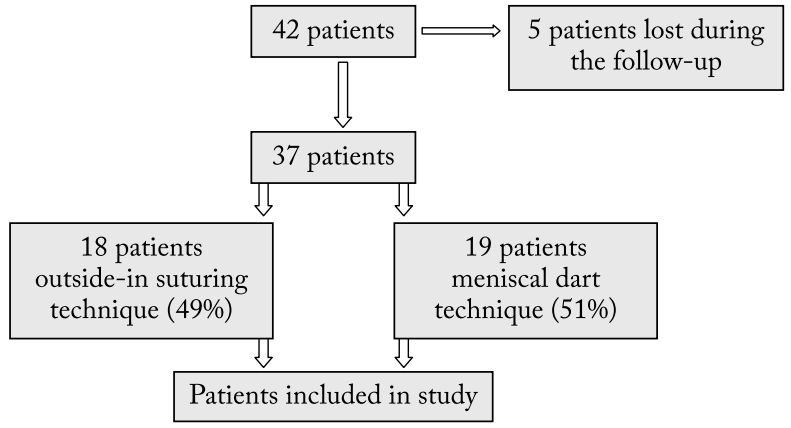

Fig. 1. Flowchart and multivariate analysis of patients included in the study.

age, sex, side involved, trauma mechanism, type of injury, anatomic localization of injury, associated injuries, complications, operating time and duration of hospital stay were analyzed. Patient data are summarized in Table 1. Based on the technique used for arthroscopic meniscal repair, patients were divided into two groups, as follows: group 1 (suturing technique; $n=18$ ) and group 2 (meniscal dart; $\mathrm{n}=19$ ) (Table 2).

\section{Hypothesis and outcome measures}

The primary endpoint of this study was to analyze clinical and subjective outcomes of patients having undergone arthroscopic meniscal repair using outside-in suturing technique and meniscal dart technique. The primary outcome measures were the International Knee Documentation Committee (IKDC) subjective knee evaluation form and Lysholm knee scoring scale. The secondary outcome variables were intraoperative and postoperative complications, duration of the operation, hospital stay, the rate of reoperations and prevalence of associated knee injuries. Intraoperative complications included injury of vascular or neural structures, incarceration of Sartorius tendon, broken retrieved instrumentation, and equipment failure or instrument breakage (heat induced or chondral injury). Postoperative complications included infection, hemarthrosis, persistent pain, swelling, stiffness, hypertrophic synovitis and compartment syndrome.

\section{Surgical treatment}

Standard anterior arthroscopy approach was used. After introduction of the arthroscope and inspection of the knee, revitalization of tear margins was performed. Two operating techniques were used. Suture techniques were selected depending on the type and 
Table 1. Patient characteristics and treatment outcomes

\begin{tabular}{|c|c|c|c|c|}
\hline Patient characteristics & & $\begin{array}{l}\text { Outside-in meniscal } \\
\text { suture technique } \\
(\mathrm{n}=18)\end{array}$ & $\begin{array}{l}\text { Meniscal dart } \\
\text { technique } \\
(\mathrm{n}=19)\end{array}$ & $p$ \\
\hline \multicolumn{5}{|l|}{ Demographic characteristic } \\
\hline $\begin{array}{l}\text { Age (years) } \\
\text { median (IQR) }\end{array}$ & & $\begin{array}{l}17 \\
(14,18)\end{array}$ & $\begin{array}{l}15.5 \\
(12,18)\end{array}$ & $0.0109^{* * *}$ \\
\hline $\begin{array}{l}\text { Gender } \\
\mathrm{n}(\%)\end{array}$ & Female & $7(39 \%)$ & $7(37 \%)$ & $0.897^{*}$ \\
\hline $\begin{array}{l}\mathrm{n}(\%) \\
\text { Knee lateralization } \\
\mathrm{n}(\%)\end{array}$ & $\begin{array}{l}\text { Male } \\
\text { Left knee } \\
\text { Right knee }\end{array}$ & \begin{tabular}{|l}
$11(61 \%)$ \\
$8(44 \%)$ \\
$10(56 \%)$
\end{tabular} & $\begin{array}{l}12(63 \%) \\
8(42 \%) \\
11(58 \%)\end{array}$ & $0.885^{*}$ \\
\hline Meniscus lateralization & Medial meniscus & $13(72 \%)$ & $13(68 \%)$ & $0.714^{\text {**** }}$ \\
\hline n (\%) & Lateral meniscus & $4(22 \%)$ & $6(32 \%)$ & \\
\hline $\begin{array}{l}\text { Anatomic location of the injury } \\
n(\%)\end{array}$ & $\begin{array}{l}\text { Both } \\
\text { Anterior horn } \\
\text { Body } \\
\text { Posterior horn }\end{array}$ & $\begin{array}{l}1(6 \%) \\
2(11 \%) \\
16(89 \%) \\
0(0 \%) \\
\end{array}$ & $\begin{array}{l}0(0 \%) \\
4(21 \%) \\
10(53 \%) \\
5(26 \%)\end{array}$ & $0.035^{* * *}$ \\
\hline \multicolumn{5}{|l|}{ Outcome } \\
\hline $\begin{array}{l}\text { Operating time (min) } \\
\text { median (IQR) }\end{array}$ & & $\begin{array}{l}62.5 \\
(60,90)\end{array}$ & $\begin{array}{l}70 \\
(70,100)\end{array}$ & $0.184^{* *}$ \\
\hline $\begin{array}{l}\text { Length of hospital stay (days) } \\
\text { median (IQR) }\end{array}$ & & $\begin{array}{l}3 \\
(2,4)\end{array}$ & $\begin{array}{l}3 \\
(2,6)\end{array}$ & $0.951^{* *}$ \\
\hline $\begin{array}{l}\text { Lysholm score } \\
\text { median (IQR) }\end{array}$ & & $\begin{array}{l}86.5 \\
(78,98)\end{array}$ & $\begin{array}{l}84.5 \\
(80,90)\end{array}$ & $0.651^{* *}$ \\
\hline $\begin{array}{l}\text { IKDC score } \\
\text { median (IQR) }\end{array}$ & & $\begin{array}{l}81.05 \\
(69,90.8)\end{array}$ & $\begin{array}{l}81.6 \\
(66.7,90.8)\end{array}$ & $0.986^{* *}$ \\
\hline Associated injuries & & 9 & 8 & $0.47^{*}$ \\
\hline Postoperative complications (n) & & 2 & 1 & $0.3^{*}$ \\
\hline Reoperations (n) & & 1 & 0 & $0.3^{*}$ \\
\hline $\begin{array}{l}\text { Follow-up (months) } \\
\text { median (IQR) }\end{array}$ & & $\begin{array}{l}40 \\
(29,119)\end{array}$ & $\begin{array}{l}25 \\
(16,57)\end{array}$ & $0.015^{* *}$ \\
\hline
\end{tabular}

$\mathrm{IQR}=$ interquartile range; $\mathrm{IKDC}=$ International Knee Documentation Committee; ${ }^{*} \chi^{2}$-test; **Mann-Whitney U test; ${ }^{* * *}$ Fisher exact test

location of meniscal tear. The outside-in technique was performed with a nonresorbable suture (Premilene $2 / 0$, Braun, Tuttlingen, Germany). The suture was introduced from outside the joint through the base of the meniscus using a cannulated needle and then pulled back out using a suture loop inserted with another cannulated needle. The U-suture is knotted over the joint capsule through a stab incision. In the allinside technique, the system for dart application includes a cannulated insertion sheath and disposable dart driver preloaded with a meniscal dart (Meniscal dart $^{\mathrm{TM}}, 1.3 \times 12 \mathrm{~mm}$, Arthrex, Karlsfeld, Germany) at its distal end. The insertion sheath is located near the meniscal tear, and sharp prongs on the tip of the sheath are used to secure and position the central fragment of the torn meniscus. The dart driver with a preloaded dart is advanced through the cannulation of the insertion sheath so that the preloaded meniscal dart at the distal end of the driver is inserted through the meniscal tear.

\section{Follow-up}

The patients were regularly followed up for 7 days, and then at 1, 3, 6 and 12 months after index surgery 
Table 2. Patient characteristics and subjective evaluation of both groups

\begin{tabular}{|c|c|c|c|c|c|c|c|c|}
\hline \multirow[b]{2}{*}{$\begin{array}{l}\text { Patient } \\
\text { No. }\end{array}$} & \multirow[b]{2}{*}{$\begin{array}{l}\text { Age } \\
\text { (years) }\end{array}$} & \multirow[b]{2}{*}{$\begin{array}{l}\text { Gender } \\
(\mathrm{F} / \mathrm{M})\end{array}$} & \multirow[b]{2}{*}{$\begin{array}{l}\text { Knee } \\
\text { (right/left) }\end{array}$} & \multirow[b]{2}{*}{ Meniscus } & \multirow[b]{2}{*}{$\begin{array}{l}\text { Anatomic localization } \\
\text { of the injury* }\end{array}$} & \multirow[b]{2}{*}{$\begin{array}{l}\text { Follow-up } \\
\text { (months) }\end{array}$} & \multicolumn{2}{|c|}{ Subjective evaluation } \\
\hline & & & & & & & $\begin{array}{l}\text { Lysholm } \\
\text { score }\end{array}$ & $\begin{array}{l}\text { IKDC } \\
\text { score }\end{array}$ \\
\hline \multicolumn{9}{|c|}{ Group 1: outside-in meniscal suture technique } \\
\hline 1 & 18 & $\mathrm{M}$ & Right & Lateral & $\mathrm{B}$ & 15 & 79 & 69 \\
\hline 2 & 17 & M & Right & Medial & B & 19 & 100 & 81.6 \\
\hline 3 & 18 & $\mathrm{~F}$ & Left & Medial & B & 24 & 89 & 37.9 \\
\hline 4 & 17 & $\mathrm{~F}$ & Right & Medial & B & 29 & 69 & 42.5 \\
\hline 5 & 17 & M & Right & Lateral & B & 29 & 100 & 95.4 \\
\hline 6 & 14 & $\mathrm{~F}$ & Right & Medial & B & 32 & 84 & 78.2 \\
\hline 7 & 14 & $\mathrm{~F}$ & Left & Medial & B & 33 & 60 & 72.4 \\
\hline 8 & 18 & M & Left & Medial & B & 38 & 90 & 90.8 \\
\hline 9 & 16 & M & Left & Medial & B & 40 & 100 & 97.7 \\
\hline 10 & 15 & M & Left & Medial & B & 40 & 76 & 100 \\
\hline 11 & 17 & $\mathrm{~F}$ & Left & Lateral & $\mathrm{AH}$ & 67 & 84 & 62.1 \\
\hline 12 & 18 & M & Left & Medial & B & 85 & 78 & 79.3 \\
\hline 13 & 15 & M & Right & Lateral & B & 97 & 98 & 97.7 \\
\hline 14 & 18 & $\mathrm{~F}$ & Left & Med./Lat. & $\mathrm{AH}$ & 119 & 74 & 69 \\
\hline 15 & 18 & M & Right & Medial & B & 120 & 78 & 90.8 \\
\hline 16 & 18 & M & Right & Medial & B & 121 & 95 & 86.2 \\
\hline 17 & 17 & M & Right & Medial & B & 124 & 97 & 88.5 \\
\hline 18 & 17 & $\mathrm{~F}$ & Right & Medial & B & 145 & 98 & 80.5 \\
\hline & & & & & Median & 40 & 86.5 & 81.05 \\
\hline \multicolumn{9}{|c|}{ Group 2: meniscal dart technique } \\
\hline 1 & 15 & $\mathrm{~F}$ & Right & Lateral & $\mathrm{AH}$ & 13 & 90 & 66.7 \\
\hline 2 & 16 & $\mathrm{~F}$ & Right & Medial & $\mathrm{AH}$ & 14 & 98 & 51.7 \\
\hline 3 & 17 & M & Right & Medial & $\mathrm{B}$ & 15 & 88 & 56.3 \\
\hline 4 & 12 & M & Right & Medial & $\mathrm{PH}$ & 15 & 90 & 73.9 \\
\hline 5 & 14 & $\mathrm{~F}$ & Left & Lateral & $\mathrm{AH}$ & 16 & 87 & 55.2 \\
\hline 6 & 15 & $\mathrm{~F}$ & Right & Medial & $\mathrm{PH}$ & 17 & 94 & 81.6 \\
\hline 7 & 13 & $\mathrm{~F}$ & Right & Medial & $\mathrm{B}$ & 21 & 84 & 66.7 \\
\hline 8 & 13 & $\mathrm{M}$ & Left & Lateral & $\mathrm{PH}$ & 24 & 100 & 96.6 \\
\hline 9 & 16 & $\mathrm{M}$ & Right & Medial & B & 25 & 65 & 90.8 \\
\hline 10 & 16 & M & Right & Lateral & B & 25 & 80 & 86.2 \\
\hline 11 & 18 & $\mathrm{M}$ & Left & Medial & $\mathrm{AH}$ & 29 & 86 & 96.6 \\
\hline 12 & 16 & $\mathrm{~F}$ & Right & Lateral & B & 30 & 68 & 67.8 \\
\hline 13 & 17 & $\mathrm{~F}$ & Left & Medial & B & 30 & 87 & 83.9 \\
\hline 14 & 15 & $\mathrm{M}$ & Left & Medial & B & 34 & 75 & 98.9 \\
\hline 15 & 18 & $\mathrm{M}$ & Right & Medial & B & 57 & 78 & 78.2 \\
\hline 16 & 15 & $\mathrm{M}$ & Right & Lateral & $\mathrm{PH}$ & 68 & 84 & 93.1 \\
\hline 17 & 14 & M & Left & Medial & $\mathrm{PH}$ & 91 & 84 & 74.7 \\
\hline 18 & 17 & $\mathrm{M}$ & Left & Medial & B & 94 & 84 & 83.9 \\
\hline 19 & 16 & $M$ & Left & Medial & B & 95 & 84 & 90.8 \\
\hline & & & & & Median & 25 & 84.5 & 81.6 \\
\hline
\end{tabular}

IKDC = International Knee Documentation Committee; $\mathrm{AH}=$ anterior horn; $\mathrm{PH}=$ posterior horn; $\mathrm{B}=$ body $\mathrm{F}=$ female; $\mathrm{M}=$ male 
using the IKDC subjective knee evaluation form and Lysholm knee scoring scale. The IKDC evaluation form was used to detect improvement or deterioration in symptoms, function and sports activities due to knee impairment. It consists of three domains, i.e. symptoms, sports and daily activities, current knee function and knee function prior to knee injury, with a total score of $100^{6}$. Lysholm knee scoring scale was used to evaluate outcomes of knee ligament surgery, particularly symptoms of instability. The revised scale includes 8 items: limp, support, locking, instability, pain, swelling, stair climbing, and squatting ${ }^{7}$.

\section{Statistical analysis}

Data were analyzed using the Microsoft Excel for Windows version 11.0 (Microsoft Corporation, Washington, WA, USA) and SPSS 19.0 (IBM Corp, Armonk, NY, USA) software programs. Distributions of quantitative data were described by median and range, whereas absolute rates and percentages were used to describe categorical data. Differences in median values of quantitative variables between the groups of patients were tested with Mann-Whitney U test. The $\chi^{2}$-test or Fisher exact test was used on statistical analysis of categorical data, depending on the distribution of data. All values of $\mathrm{p}<0.05$ were considered to indicate statistical significance.

\section{Results}

There was no statistically significant gender difference between the two groups ( $\mathrm{p}=0.897)$ (Table 1$)$. Median patient age was 17 (IQR 14,18) years in the meniscal suture group and 15.5 (IQR 12,18$)$ years in the meniscal dart group ( $\mathrm{p}=0.0109)$ (Table 1$)$.

According to lateralization of the injured knee, in the meniscal suture group left knee was injured in eight (44\%) and right knee in ten (56\%) patients, whereas in the meniscal dart group left knee was affected in eight (42\%) and right knee in 11 (58\%) patients. There was no statistically significant difference between the two groups according to lateralization of the injury $(\mathrm{p}=0.885)$ (Table 1$)$.

In the meniscal suture group, medial meniscus was ruptured in 13 (72\%), lateral meniscus in four (22\%) patients and both menisci in one $(6 \%)$ patient. In the meniscal dart group, medial meniscus was ruptured in
$13(68 \%)$ and lateral meniscus in six (32\%) patients. There was no statistically significant difference between the two groups according to affection of meniscal lateralization ( $\mathrm{p}=0.714)$ (Table 1$)$.

Anterior horn of meniscus was injured in two (11\%) and body of meniscus in 16 (89\%) patients in the meniscal suture group. In the meniscal dart group, anterior horn was injured in four (21\%), body in ten (53\%) and posterior horn in five (26\%) patients. Statistically significant difference between the two groups was found according to anatomic location of meniscal rupture $(\mathrm{p}=0.035)($ Table 1$)$.

Median of operation time was 62.5 (IQR 60, 90) min in the meniscal suture group and 70 (IQR 70, 100) $\mathrm{min}$ in the meniscal dart group. Median of the length of hospital stay was 2 days in both groups. There was no statistically significant between-group difference in the operation time $(\mathrm{p}=0.184)$ and length of hospital stay $(\mathrm{p}=0.95)$ (Table 1$)$.

Median of the Lysholm knee score was 86.5 (IQR 78,98 ) for the meniscal suture group and 84.5 (IQR 80, 90) for the meniscal dart group.

Median of the IKDC subjective knee evaluation form was 81.05 (IQR 69,90.8) for the meniscal suture group and 81.6 (IQR 66.7,90.8) for the meniscal dart group. There was no statistically significant difference between the two groups according to Lysholm knee score $(\mathrm{p}=0.651)$ and IKDC score $(\mathrm{p}=0.986)$ (Table 1$)$.

Median of the length of follow-up in months was 40 (IQR 29,119) for the meniscal suture group and 25 (IQR 16, 57) for the meniscal dart group, yielding a statistically significant between-group difference $(\mathrm{p}=0.015)$ (Table 1$)$.

There were no intraoperative complications recorded. There were $3(8.1 \%)$ postoperative complications, i.e. $2(5.4 \%)$ wound infections (one in each group) and $1(2.7 \%)$ postoperative stiffness in the outside-in meniscal suture group. The patient with postoperative stiffness was reoperated on.

Out of 37 patients included in the study, 17 (46\%) patients had associated one or more knee injuries due to the event that led to meniscal injury, i.e. eight (21\%) patients in the meniscal suture group and nine (24\%) patients in the meniscal dart group. There was no statistically significant difference between the two groups according to the prevalence of associated knee injuries $(\mathrm{p}=0.47)$ (Table 3). 
Table 3. Type and incidence of associated injuries

\begin{tabular}{|l|l|l|}
\hline Associated injury & $\mathrm{n}$ & Percent \\
\hline $\begin{array}{l}\text { Ligament injury } \\
\text { Partial anterior cruciate ligament } \\
\text { rupture }\end{array}$ & $\mathbf{1 1}$ & $\mathbf{5 5 \%}$ \\
$\begin{array}{l}\text { Total anterior cruciate ligament } \\
\text { rupture }\end{array}$ & 7 & $20 \%$ \\
Chondral injury & $\mathbf{5}$ & $\mathbf{2 5 \%}$ \\
Medial femoral condyle contusion & 3 & $15 \%$ \\
Lateral femoral condyle contusion & 1 & $5 \%$ \\
Intercondylar eminence contusion & 1 & $5 \%$ \\
Patella injury & $\mathbf{3}$ & $\mathbf{1 5 \%}$ \\
Patella contusion & 2 & $10 \%$ \\
Pattelo-tibial membrane rupture & 1 & $5 \%$ \\
Miscellaneous & 1 & $\mathbf{5 \%}$ \\
Hemarthrosis & 1 & $5 \%$ \\
Total associated injuries & $\mathbf{2 0}$ & $\mathbf{1 0 0 \%}$ \\
\hline
\end{tabular}

Concerning injury mechanisms of meniscal rupture, sports activities were the dominant cause. Soccer players were the most likely athletes to sustain a meniscal injury (36\%), followed by handball (19\%), volleyball (11\%), fight sports (8\%), weightlifting (6\%), dancing and rock climbing ( $1 \%$ both), and other sports or activities.

\section{Discussion}

Meniscal tears are the most common knee injuries showing an increasing tendency in pediatric patients ${ }^{8}$. The adolescent meniscus is better vascularized and indications for repair should be extended to avascular zones with satisfactory result ${ }^{2,9}$. Meniscal repairs have better long-term patient-reported outcomes and better activity levels than meniscectomy; besides, the former meniscal repairs have a lower failure rate ${ }^{10}$.

In our study, there were no statistically significant between-group differences according to patient gender and these results are consistent with the results reported by Schmitt et al. on $63 \%$ of boys and $37 \%$ of girls in their study ${ }^{8}$. Regarding lateralization of the injured knee, $42 \%$ of patients had left knee and 58\% right knee injured. Schmitt et al. and Lucas et al. report on similar findings in their studies ${ }^{8,11}$.

Medial meniscus is more commonly injured because it is firmly attached to the medial collateral liga- ment and joint capsule, while lateral meniscus is more mobile than medial meniscus as there is no attachment to the lateral collateral ligament or joint capsule. Similar distribution regarding meniscal injury lateralization was found in our study.

Anatomic location of meniscal rupture influences the choice of the repair technique. Suturing is used when the rupture is located on the menisco-capsular junction and in the 'bucket handle' types of rupture in the middle part of the meniscus, while the outside-in technique is the best for the anterior horn ruptures, which coincides with the results of two studies conducted by Post et al..$^{12}$ and Rodeo ${ }^{13}$. Meniscal fixation by dart is used for ruptures in the posterior part of the meniscus because this technique decreases the possible neurovascular structure injury ${ }^{14}$.

The length of hospital stay was 2 days in both groups. According to the National Health Care System guidelines, patients having undergone only meniscal or chondral operation are supposed to be hospitalized for 1 day, but in our hospital patients immediately start with physical therapy and rehabilitation, which was the reason for longer hospital stay in our patients ${ }^{15}$.

There were no statisticaly significant differences according to Lysholm knee score and IKDC subjective knee evaluation between the two groups. In the suture group, median of Lysholm score was 86.5. Similar score of 87.29 is reported by Abdelkafy et al. ${ }^{16}$. Sobhy et al. report median Lysholm (34 to 88) and median IKDC subjective scores (25 to 88 ) for the outside-in technique follow-up ${ }^{17}$.

Schmitt et al. report the mean IKDC score 90.7 and mean Lysholm score 95 for the all-inside meniscal repair techniques in pediatric patients, which is slightly different from our median IKDC score 81.6 and median Lysholm score 84.5 for the meniscal dart group $^{8}$. Haas et al. report results of postoperative IKDC 92, confirming the all-inside technique to be safe and efficient for meniscal repair ${ }^{18}$.

Regarding complications, the overall rate of $8.1 \%$ recorded in our study was lower than the $18 \%$ overall complication rate in the study by Austin et al. for complications of arthroscopic meniscal repair ${ }^{19}$. We report only one case of postoperative stiffness that required redo surgery. Schmitt et al. also report a case of postoperative stiffness, which resolved within a few weeks by physiotherapy $^{8}$. 
Subsequent to the meniscal injury, a high percent of patients with acute traumatic meniscal rupture sustained an anterior cruciate ligament (ACL) injury. ACL injury is connected to meniscal injuries because knee ligaments have a protective role on the menisci. About $50 \%$ of patients with meniscal tear have ACL injury, which is consistent with our result of $55 \% \mathrm{ACL}$ injuries ${ }^{20}$.

Compared to the study by Kilcoyne et al. ${ }^{20}$, which studied epidemiology of meniscal injuries associated with ACL tears in young athletes, our results are quite different. Kilcoyne et al. found wrestling and volleyball as the sports that had the highest incidence of meniscal injury ${ }^{20}$, and in our study soccer had the highest incidence as injury mechanism.

Results of both meniscal repair techniques showed high success rates in terms of resolution of symptoms and healing rate. Torn meniscus requires postoperative protection to allow healing and physical therapy to regain function of the knee very soon after surgery. All torn menisci in our series healed with excellent results. The patients resumed their daily activities very soon.

We note several limitations to this study. Literature data on the clinical results of meniscal repairs are variable because of different inclusion criteria. Numerous all-inside meniscal repair devices have been developed, so it is hard to compare just meniscal dart as one option of the all-inside meniscal repair devices to the outside-in suture technique. In addition, the study included a small number of patients because of the low frequency of meniscal lesions in adolescents, and some of the patients were lost due to the high mobility of pediatric population having grown into adulthood.

\section{Conclusion}

Understanding the harmful impact of meniscectomy, arthroscopic meniscal repair should be attempted whenever possible and applied in children and adolescents as well. Both the outside-in suture technique and all-inside meniscal repair technique by using darts provided satisfactory functional results in this study. Our data support routine arthroscopic repair of meniscal tears, with good long-term results and low risk of complications.

\section{References}

1. Furlan D, Pogorelić Z, Jurić I, Meštrović J, Furlan M, Biočić M. Comparison between plaster cast immobilization and semirigid immobilization in children and adolescents with injuries of the knee. Pediatr Croat. 2010;54:183-7.

2. Rubman MH, Noyes FR, Barber-Westin SD. Arthroscopic repair of meniscal tears that extend into the avascular zone. Am J Sports Med. 1998;26:87-95. https://doi.org/10.1177/0363546 5980260013301

3. Greis PE, Bardana DD, Holmstrom MC, Burks RT. Meniscal injury: I. Basic science and evaluation. J Am Acad Orthop Surg. 2002;10:168-76. https://doi.org/10.1177/0363546502030004 2001

4. Salata MJ, Gibbs AE, Sekiya JK. A systematic review of clinical outcomes in patients undergoing meniscectomy. Am J Sports Med. 2010;38:1907-16. https://doi.org/10.1177/0363546510 370196

5. Laprell H, Stein V, Petersen W. Arthroscopic all-inside meniscus repair using a new refixation device: a prospective study. Arthroscopy. 2002;18:387-93. https://doi.org/10.1053/jars.2002.30639

6. Furlan D, Pogorelić Z, Biocić M, Jurić I, Mestrović J. Pediatric tibial eminence fractures: arthroscopic treatment using K-wire. Scand J Surg. 2010;99:38-44. https://doi.org/10.1177/1457 49691009900109

7. Lysholm J, Gillquist J. Evaluation of knee ligament surgery results with special emphasis on use of a scoring scale. Am J Sports Med. 1982;10:150-4. https://doi.org/10.1177/036354 658201000306

8. Schmitt A, Batisse F, Bonnard C. Results with all-inside meniscal suture in pediatrics. Orthop Traumatol Surg Res. 2016;102:207-11. https://doi.org/10.1016/j.otsr.2015.12.018

9. Petersen W, Tillmann B. Age-related blood and lymph supply of the knee menisci. A cadaver study. Acta Orthop Scand. 1995;66:308-12.https://doi.org/10.3109/17453679508995550

10. $\mathrm{Xu} \mathrm{C}, Z$ hao J. A meta-analysis comparing meniscal repair with meniscectomy in the treatment of meniscal tears: the more meniscus, the better outcome? Knee Surg Sports Traumatol Arthrosc. 2015;23:164-70. https://doi.org/10.1007/s00167-013$2528-6$

11. Lucas G, Accadbled F, Violas P, Sales de Gauzy J, Knörr J. Isolated meniscal injuries in paediatric patients: outcomes after arthroscopic repair. Orthop Traumatol Surg Res. 2015;101:1737. https://doi.org/10.1016/j.otsr.2014.12.006

12. Post WR, Akers SR, Kish V.Load to failure of common meniscal repair techniques: effects of suture technique and suture material.Arthroscopy. 1997;13:731-6. https://doi.org/10.1016/ s0749-8063(97)90008-6

13. Rodeo SA. Arthroscopic meniscal repair with use of the outside-in technique. Instr Course Lect. 2000;49:195-206.

14. Whitman T, Diduch D. Case report transient posterior knee pain with the meniscal arrow. Arthrosc J Arthrosc Relat Surg. 1998;14:762-3. https://doi.org/10.1016/s0749-8063(98) 70107-0 
15. Osti L, Del Buono A, Maffulli N. Anterior medial meniscal root tears: a novel arthroscopic all inside repair. Transl Med UniSa. 2014;12:41-6.

16. Abdelkafy A, Aigner N, Zada M, Elghoul Y, Abdelsadek H, Landsiedl F. Two to nineteen years follow-up of arthroscopic meniscal repair using the outside-in technique: a retrospective study. Arch Orthop Trauma Surg. 2007;127:245-52. https:// doi.org/10.1007/s00402-006-0139-0

17. Sobhy MH, AbouElsoud MMS, Kamel EM, Desouki AM. Neurovascular safety and clinical outcome of outside-in repair of tears of the posterior horn of the medial meniscus. Arthroscopy. 2010;26:1648-54. https://doi.org/10.1016/j.arthro.2010.05.018
18. Haas AL, Schepsis AA, Hornstein J, Edgar CM. Meniscal repair using the FasT-Fix all-inside meniscal repair device. Arthrosc J Arthrosc Relat Surg. 2005;21:167-75. https://doi. org/10.1016/j.arthro.2004.10.012

19. Austin KS, Sherman OH. Complications of arthroscopic meniscal repair. Am J Sports Med. 1993;21:864-9. https://doi. org/10.1177/036354659302100619

20. Kilcoyne KG, Dickens JF, Haniuk E, Cameron KL, Owens BD. Epidemiology of meniscal injury associated with ACL tears in young athletes. Orthopaedics. 2012;35:208-12. https:// doi.org/10.3928/01477447-20120222-07

\title{
Sažetak \\ ARTROSKOPSKO LIJEČENJE OZLJEDA MENISKA U ADOLESCENATA: USPOREDBA TEHNIKE ŠIVANJA IZVANA-UNUTRA I MENISKEALNIH STRELICA
}

\author{
Z. Pogorelic, E. Puizina, M. Jukić, J. Meštrović, I. Pintarić i D. Furlan
}

Cilj ovoga istraživanja je bio analizirati kliničke i subjektivne ishode liječenja u bolesnika operiranih zbog ozljeda meniska te usporediti dvije skupine bolesnika operiranih različitim tehnikama popravka meniska. Od siječnja 2006. do lipnja 2017. godine u studiju je uključeno 37 bolesnika koji su liječeni artroskopski zbog rupture meniska. Bolesnici su podijeljeni u dvije skupine ovisno o vrsti kirurškog zahvata: jednu skupinu skupinu činilo je 18 bolesnika u kojih je meniskus šivan tehnikom postavljanja šavova, a drugu 19 bolesnika u kojih su upotrebljene strelice za fiksaciju meniska. Svakom ispitaniku analizirani su sljedeći parametri: dob, spol, mehanizam nastanka ozljede, lateralizacija ozljede i meniska, anatomska lokalizacija ozljede i pridružene ozljede. Ispitanicima koji su podvrgnuti tehnikama popravka meniska analizirani su još i vrsta kirurške tehnike popravka meniska, rezultati subjektivne evaluacije 4 tjedna nakon operacije putem upitnika Lysholm i IKDC (International Knee Documentation Committee) te komplikacije nakon operacije. Između skupina bolesnika operiranih tehnikom postavljanja šavova i tehnikom fiksacije meniska strelicama nije bilo značajne razlike u promatranim ishodima liječenja, osim za anatomsku lokalizaciju ozljede $(\mathrm{p}=0,035)$. Medijani operacijskog vremena u skupini bolesnika operiranih tehnikom postavljanja šavova iznosio je $62,5 \mathrm{~min}$, dok je u skupini fiksacije meniska strelicama medijan operacijskog vremena iznosio 70 minuta $(\mathrm{p}=0,184)$. Medijan duljine hospitalizacije bio je 2 dana za obje skupine ( $\mathrm{p}=0,951)$. Medijan vrijednosti ljestvice Lysholm za promatrane skupine bio je 86,5 i 84,5 ( $p=0,651$ ), a ljestvice IKDC 81,05 i 81,6 ( $p=0,986$ ). Poznavajući štetne učinke meniskektomije, tehnika popravka meniska je dugoročnije bolji odabir i trebala bi se provoditi kadgod je to moguće. Obje tehnike (tehnika postavljanja šavova i tehnika fiksacije meniska strelicama) su sigurne i uspješne u liječenju ruptura meniska u djece, bez značajnijih komplikacija te s dobrim dugoročnim rezultatima.

Ključne riječi: Menisk; Popravak meniska; Djeca; Strelice za menisk; Šivanje; Artroskopija 